Cochrane Database of Systematic Reviews

\title{
Gene therapy for sickle cell disease (Review)
}

Olowoyeye A, Okwundu Cl

Olowoyeye A, Okwundu Cl.

Gene therapy for sickle cell disease.

Cochrane Database of Systematic Reviews 2018, Issue 11. Art. No.: CD007652.

DOI: 10.1002/14651858.CD007652.pub6.

www.cochranelibrary.com 
TABLE OF CONTENTS

HEADER 1

ABSTRACT

PLAIN LANGUAGE SUMMARY

BACKGROUND

OBJECTIVES

METHODS

RESULTS

DISCUSSION

AUTHORS' CONCLUSIONS

ACKNOWLEDGEMENTS

REFERENCES

APPENDICES

WHAT'S NEW

HISTORY

CONTRIBUTIONS OF AUTHORS

DECLARATIONS OF INTEREST

SOURCES OF SUPPORT

DIFFERENCES BETWEEN PROTOCOL AND REVIEW

INDEX TERMS

1

2

3

4

4

5

5

5

6

7

8

8

9

9

9

9

9 
[Intervention Review]

\section{Gene therapy for sickle cell disease}

Abiola Olowoyeye ${ }^{1}$, Charles I Okwundu²

${ }^{1}$ Children's Hospital Los Angeles, Los Angeles, California, USA. ${ }^{2}$ Centre for Evidence-based Health Care, Faculty of Medicine and Health Sciences, Stellenbosch University, Cape Town, South Africa

Contact address: Abiola Olowoyeye, Children's Hospital Los Angeles, 1520 Rodney Drive apt 216, Los Angeles, California, USA. aolowoyeye@hotmail.com.

Editorial group: Cochrane Cystic Fibrosis and Genetic Disorders Group.

Publication status and date: New search for studies and content updated (no change to conclusions), published in Issue 11, 2018.

Citation: Olowoyeye A, Okwundu Cl. Gene therapy for sickle cell disease. Cochrane Database of Systematic Reviews 2018, Issue 11. Art. No.: CD007652. DOI: 10.1002/14651858.CD007652.pub6.

Copyright (c) 2018 The Cochrane Collaboration. Published by John Wiley \& Sons, Ltd.

\section{A B S T R A C T}

\section{Background}

Sickle cell disease encompasses a group of genetic disorders characterized by the presence of at least one hemoglobin S ( $\mathrm{Hb}$ S) allele, and a second abnormal allele that could allow abnormal hemoglobin polymerisation leading to a symptomatic disorder.

Autosomal recessive disorders (such as sickle cell disease) are good candidates for gene therapy because a normal phenotype can be restored in diseased cells with only a single normal copy of the mutant gene. This is an update of a previously published Cochrane Review.

\section{Objectives}

The objectives of this review are:

- to determine whether gene therapy can improve survival and prevent symptoms and complications associated with sickle cell disease;

- to examine the risks of gene therapy against the potential long-term gain for people with sickle cell disease.

\section{Search methods}

We searched the Cochrane Cystic Fibrosis and Genetic Disorders Group Haemoglobinopathies Trials Register, which comprises of references identified from comprehensive electronic database searches and searching relevant journals and abstract books of conference proceedings. We also searched online trial registries,

Date of the most recent search of the Group's Haemoglobinopathies Trials Register: 19 July 2018.

\section{Selection criteria}

All randomised or quasi-randomised clinical trials (including any relevant phase 1, 2 or 3 trials) of gene therapy for all individuals with sickle cell disease, regardless of age or setting.

\section{Data collection and analysis}

No trials of gene therapy for sickle cell disease were found.

\section{Main results}

No trials of gene therapy for sickle cell disease were reported. 


\section{Authors' conclusions}

No randomised or quasi-randomised clinical trials of gene therapy for sickle cell disease were reported. Thus, no objective conclusions or recommendations in practice can be made on gene therapy for sickle cell disease. This systematic review has identified the need for welldesigned, randomised controlled trials to assess the benefits and risks of gene therapy for sickle cell disease.

\section{PLAIN LANGUAGE SUMMARY}

\section{Gene therapy for sickle cell disease}

\section{Review question}

We reviewed the evidence about the effect and safety of gene therapy on survival and on preventing symptoms and complications associated with sickle cell disease.

\section{Background}

Sickle cell disease results when a child inherits faulty genes for producing haemoglobin from both parents. It is a disease that is linked with frequent illness from early life and often results in death earlier than in the general population. Gene therapy replaces these faulty genes with normal ones.

\section{Search date}

The evidence is current to: 19 July 2018.

\section{Key results}

We looked for trials that used this approach of replacing faulty genes for producing haemoglobin with normal ones in the treatment of sickle cell disease. We found no trials to provide reliable evidence about the risks or benefits of gene therapy for this condition. There is a need for trials that assess the benefits or risks of gene therapy for sickle cell disease. 


\section{B A C K G R O U N D}

\section{Description of the condition}

Sickle cell disease (SCD) is a group of genetic conditions that result from the inheritance of abnormal haemoglobin genes, thereby resulting in the production of abnormal haemoglobin in red blood cells (Akinyanju 1989). Haemoglobin is responsible for transporting oxygen around the body packaged in red blood cells. In people with SCD, the red blood cells contain abnormal haemoglobin and change from their normal round disk shape to narrow sickle forms. The sickle shape is the end result of a series of complex biochemical and biophysical events within the red cell after deoxygenation of $\mathrm{Hb}$ S. The sickle-shaped cells do not flow smoothly through small blood vessels the way disk-shaped red blood cells do; they block the vessels, causing pain and organ damage.

About $5 \%$ of the world's population carry genes responsible for haemoglobinopathies with most of the people living in, or originating from sub-Saharan Africa (WHO 2006). Each year about 300,000 infants are born with major haemoglobin disorders, including more than 200,000 cases of sickle cell anaemia in Africa (WHO 2006). Some parts of Africa have up to $10 \%$ to $30 \%$ of the population with the sickle cell trait and approximately $8 \%$ of people of African descent carry one sickle gene in the United States of America (USA) and the Caribbean (Ohene-Frempong 1994; Serjeant 1992).

Although inheriting a single abnormal sickle gene may protect against the severe form of malaria caused by Plasmodium falciparum, inheritance of two abnormal sickle genes (one from each parent) leads to sickle cell anaemia and confers no such protection. Malaria is a major cause of ill-health and death in children with sickle cell anaemia. In addition to its health implications, SCD also impacts on individuals and their families both socially and psychologically when trying to meet the demands of this chronic illness. SCD often also interferes with educational development due to its unpredictable and debilitating nature. There is a higher incidence of school absenteeism and hospital costs in families that have a child with SCD (Manci 2003; Platt 1991; Powars 2002; Serjeant 1993). Life expectancy is on the rise for people with SCD, but is still less than that of the general population (Platt 1994).There are no firm data on the survival of individuals with sickle cell anaemia on the African continent (Platt 1991).The median survival was estimated in 1994 to be 42 years for men and 48 years for women in the USA, whereas comparable figures for Jamaica published in 2001 suggested 53 years for men and 58.5 years for women (Platt 1991). The mortality rate is higher amongst people with SCD, and is usually caused either by chronic organ failure consequent on the sickling process, or as a result of an acute catastrophic event, such as a stroke (Powars 1983); acute sickle chest syndrome; splenic sequestration (Steinberg 2003); sudden death or other complications (Gray 1991).

Management of SCD is multidisciplinary. Penicillin prophylaxis to prevent pneumococcal infections, appropriate use of blood transfusions and other supportive measures have improved survival of people with SCD (Gaston 1986; Lezcano 2006). Hydroxycarbamide (hydroxyurea) made a major impact on sickle cell therapy when it was shown to reduce morbidity and mortality (Steinberg 2003). Bone marrow transplantation remains the only possible curative therapy (Mankad 2001). Although palliative therapies and bone marrow transplantation therapy have been developed for these disorders, treatment still remains sub-optimal and many individuals suffer significant morbidity and early mortality (Persons 2003). Therefore, development of a gene therapy approach has been sought for many years (Nathan 2001; Persons 2003).

\section{Description of the intervention}

Gene therapy holds a great deal of promise for the future of medical treatment. It involves the introduction of genetic material into a cell to treat disease. The momentum was generated in 2000 when it was demonstrated that lentivirus vectors containing normal human globin genes and regulatory regions from the beta-globin locus control region could be faithfully transduced into mouse hematopoietic stem cells and expressed in erythroid cells (Bodine 2003; May 2000).

\section{How the intervention might work}

Gene therapy is the introduction of genes into an individual's cells and tissues in order to treat a disease. Most of the conditions treated in this way are genetic disorders that result from gene mutation malfunctions (Postnote 2005). Viruses are the most widely used vectors in gene therapy. Some of the different types of viruses used as vectors in gene therapy include: retroviruses; adenoviruses; adeno-associated virus; parvovirus; herpes simplex virus; hepatitis virus; and vaccinia virus (Postnote 2005). The viral vectors are made harmless by removing the viral gene and replacing them with the therapeutic gene. This approach is known as gene addition (the transfer of normal beta globin gene into hematopoietic cells via retroviral vectors or adeno-associated viruses that have been modified or crippled so they do not become infective). In theory, the viral vectors used in gene therapy are made harmless to prevent them from replicating and causing unwanted effects. However, these viruses could trigger unwanted immune responses and cause unwanted side effects.

Other approaches of gene therapy that have been developed include gene replacement (targeted insertion of the transferred gene into the endogenous globin locus by homologous recombination) and gene repair or chimeroplasty (introduction of chimeric oligonucleotides composed of DNA and modified RNA residues into stem cells to direct correction of the mutation in the sickle gene).

Good candidates for gene therapy include autosomal recessive disorders (such as SCD) because a normal phenotype can be restored in diseased cells with only a single normal copy of the mutant gene (Goncz 2002). Gene therapy, if successful, will provide a viable alternative for permanent correction of the abnormal gene in SCD. It will circumvent the problem of donor shortage and avoid complications related to graft versus host rejection that are involved with bone marrow or other forms of stem cell transplant. Gene therapy has been used to correct SCD in mice (Nathan 2001). Despite the technical problems faced, major progress in the globin gene therapy field has been achieved. This progress has advanced the possibility of gene therapy for haemoglobin disorders in the near future (Persons 2003; Chang 2006). The first successful use of gene therapy in humans for SCD has been reported; the investigators used a lentivirus to achieve integration of a normal beta globin gene into the participants hematopoetic cells (Ribeil 2017). A further clinical trial using the lentivirus is ongoing by other researchers (Kohn 2014). 
This Cochrane Review is an update of previously published versions (Olowoyeye 2010; Olowoyeye 2012).

\section{O B JE C T IVES}

The objectives of this review are to:

1. determine whether gene therapy can improve survival and prevent symptoms and complications associated with SCD;

2. examine the risks of gene therapy against the potential longterm gain for people with SCD.

\section{METHODS}

\section{Criteria for considering studies for this review Types of studies}

Randomised control trials or quasi-randomised trials. We plan to include any relevant phase I, II and III trials.

\section{Types of participants}

People of any age and sex with SCD of all phenotypes and regardless of geographic or healthcare setting.

\section{Types of interventions}

Gene therapy (any approach) plus standard treatment versus standard treatment or other 'curative' type treatment such as bone marrow transplantation, stem cell transplantation or cord blood transplantation.

\section{Types of outcome measures}

\section{Primary outcomes}

1. Event-free survival (individuals alive and free of SCD symptoms)

2. Change in mean life expectancy of individuals with SCD attributable to gene therapy

\section{Secondary outcomes}

1. Changes in haematocrit (as measured by the primary trial)

2. Severity as assessed by changes in complications associated with SCD (e.g. acute chest syndrome, strokes, chronic renal failure, liver and gallbladder diseases, leg ulcers, sequestration crises, etc)

3. Number of hospital visits and admissions as a result of pain crises and complications

4. Change in use of blood transfusion, hydroxyurea and other treatment modalities

5. Cost effectiveness of gene therapy

\section{Adverse events}

As measured by the primary trials.

\section{Search methods for identification of studies}

We searched for all relevant published and unpublished trials without restrictions on language, year or publication status.

\section{Electronic searches}

We searched the Group's Haemoglobinopathies Trials Register using the terms: (sickle cell OR (haemoglobinopathies AND general)) AND gene therapy.

The Haemoglobinopathies Trials Register is compiled from electronic searches of the Cochrane Central Register of Controlled Trials (CENTRAL) (updated each new issue of the Cochrane Library) and weekly searches of MEDLINE. Unpublished work is identified by searching the abstract books of five major conferences: the European Haematology Association conference; the American Society of Hematology conference; the British Society for Haematology Annual Scientific Meeting; the Caribbean Public Health Agency Annual Scientific Meeting (formerly the Caribbean Health Research Council Meeting); and the National Sickle Cell Disease Program Annual Meeting. For full details of all searching activities for the register, please see the relevant section of the Cochrane Cystic Fibrosis and Genetic Disorders Group's website.

Date of the most recent search of the Cystic Fibrosis and Genetic Disorders Group's Haemoglobinopathies Trials Register: 19 July 2018.

We searched the following trials registries (August 2018)

- The World Health Organization International Clinical Trials Registry Platform (www.who.int/trialsearch);

- ClinicalTrials.gov (www.clinicaltrials.gov).

\section{Searching other resources}

Reference lists of all identified papers were to be screened for relevant trials.

\section{Data collection and analysis}

Two authors, with the assistance of the Cystic Fibrosis and Genetic Disorders Group, undertook searches for eligible trials.

We were unable to identify any randomised controlled trials eligible for inclusion in this review, thus we could not perform the selection process and data analyses that we had planned. If, in the future, we identify any trials and include them in the review, we will adhere to the methods described in detail below in the remainder of this section.

\section{Selection of studies}

Two authors (OA, OC) plan to independently undertake a critical appraisal of any identified trial to establish the possible relevance of each article for inclusion in the review.

\section{Data extraction and management}

We plan to design a data extraction form and independently extract data using the agreed form. Both authors will verify the extracted data. Extracted information will include the following.

1. Trial details: citation; trial population demographics; trial design; time period; population size; attrition rate; and source of funding.

2. Outcome details: as outlined in Types of outcome measures. 
In the event that the authors disagree on the abstraction of trial details, they will contact the editor of the review to resolve the conflict.

$\mathrm{OA}$ and $\mathrm{OC}$ will extract and enter all the data and both authors will re-check all the entries. We will aim to resolve disagreements by discussion.

\section{Assessment of risk of bias in included studies}

The risk of bias will be assessed using the following domains:

- sequence generation;

- allocation concealment;

- masking of participants, personnel and outcome assessors;

- completeness of data for each main outcome;

- selective outcome reporting;

- other sources of bias.

These will be judged as being 'Yes', 'No' or 'Unclear' by using the Cochrane's tool for assessing the risk of bias (Higgins 2008).

\section{Measures of treatment effect}

For binary outcome measures, we aim to calculate a pooled estimate of the treatment effect for each outcome across trials using the risk ratio (RR) where appropriate. For continuous outcomes, we plan to record either mean relative change from baseline for each group or mean post-treatment or intervention values and standard deviation. If standard errors are reported, and where possible, these will be converted to standard deviations. We will calculate a pooled estimate of treatment effect by calculating the mean difference (MD) and 95\% confidence intervals (Cls)

\section{Dealing with missing data}

We will attempt to reach the principal investigators of the trials in the event of any missing data or the need for any clarification about the trials.

In order to allow an intention-to-treat analysis, we will seek data on the number of participants with each outcome event, by allocated treated group, irrespective of compliance and whether or not the participant was later thought to be ineligible or otherwise excluded from treatment or follow up.

\section{Assessment of heterogeneity}

We will calculate whether statistical heterogeneity is present using the $\mathrm{Chi}^{2}$ test for homogeneity $(\mathrm{P}<0.1)$. The impact of statistical heterogeneity will be quantified using the $I^{2}$ statistic, which describes the percentage of total variation across trials that is due to heterogeneity rather than sampling error (Higgins 2003).

\section{Assessment of reporting biases}

We will attempt to assess whether our review is subject to publication bias by using a funnel plot. If asymmetry is detected, causes other than publication bias will be explored.

\section{Data synthesis}

If the trials are found to be clinically homogenous, meta-analysis will be conducted. For comparable trials, we will summarize their findings using a fixed-effect model. We shall consider the appropriateness and value of a meta-analysis if there is significant clinical heterogeneity among the included trials.

\section{Subgroup analysis and investigation of heterogeneity}

In the event of significant heterogeneity, we plan to explore the possible causes by undertaking the following subgroup analyses: gene therapy technique; age; sex; and type of SCD.

\section{Sensitivity analysis}

We plan to perform a sensitivity analysis based on the generation of the allocation sequence within the trials (including and excluding quasi-randomised trials).

\section{RESULTS}

\section{Description of studies}

No trials were found that were eligible for inclusion in this review. Two studies were identified by the search of trial registries, neither of which required further investigation (Kohn 2014; Ribeil 2017).

\section{Risk of bias in included studies}

No trials were eligible for inclusion in the review

\section{Effects of interventions}

No trials were eligible for inclusion in the review.

\section{DISCUSSION}

Gene therapy aims to replace a defective gene with a normal one. Though no trials were found that are eligible for inclusion in this review, the fact that gene therapy is an evolving field assures us that trials will be available in the future. These trials will then form the basis with which an objective assessment of the benefits versus the risks of gene therapy for SCD can be made.

There are animal-based studies of gene therapy that are not eligible for inclusion in this review (Nathan 2001). However, there is a long way between the potential and the actual benefits of gene therapy for SCD compared to the risks of this intervention.

Currently, there is no information contained within any of the databases we searched on gene therapy for SCD, so no objective discussion on the risks, benefits or otherwise can yet be made.

\section{AUTHORS' CONCLUSIONS}

\section{Implications for practice}

No randomised controlled trials of gene therapy for sickle cell disease (SCD) were found for inclusion in this review. Thus, no objective conclusions or recommendations for practice can be made on gene therapy for SCD.

\section{Implications for research}

This systematic review has identified the need for well-designed and possibly multicentred randomised controlled trials to assess the benefits and risks of gene therapy for SCD. The primary outcome for these trials should be a cure for SCD, where individuals survive and are free of SCD symptoms. Also, because of the potential side effects of using viruses as vectors in gene therapy, 
further progress in new non-viral vector development is necessary. The current viral vectors should be used with caution in humans.

\section{ACKNOWLEDGEMENTS}

We like to express profound gratitude to the Managing Editor of the

Cystic Fibrosis and Genetic Disorders Group, Tracey Remmington, for her outstanding contribution to this review. We also thank the peer reviewers and the Information Specialist for their input. 


\section{REFERE N C E S}

\section{Additional references}

\section{Akinyanju 1989}

Akinyanju 0O. A profile of sickle cell disease in Nigeria. Annals of the New York Academy of Sciences 1989;565:126-36.

\section{Bodine 2003}

Bodine DM. Gene therapy for sickle cell disease marches on. Blood 2003;102:4247.

\section{Chang 2006}

Chang JC, Kan YW. Correction of the sickle cell mutation in embryonic stem cells. Proceedings of the National Academy of Sciences of the United States of America 2006;103(4):1036-40.

\section{Gaston 1986}

Gaston MH, Verter JI, Woods G, Pegelow C, Kelleher J, Presbury $\mathrm{G}$, et al. Prophylaxis with oral penicillin in children with sickle cell anemia. A randomized trial. New England Journal of Medicine 1986;314(25):1593-9.

\section{Goncz 2002}

Goncz KK, Prokopishyn NL, Chow BL, Davis BR, Gruenert DC. Application of SFHR to gene therapy of monogenic disorders. Gene Therapy 2002;9(11):691-4.

\section{Gray 1991}

Gray A, Anionwu EN, Davies SC, Brozovic M. Mortality in sickle cell disease: the experience of a British centre. Journal of Clinical Pathology 1991;44(6):459-63.

\section{Higgins 2003}

Higgins JPT, Thompson SG, Deeks JJ, Altman DG. Measuring inconsistency in meta-analysis. BMJ 2003;327(7414):557-60.

\section{Higgins 2008}

Higgins JPT, Altman DG (editors). Assessing risk of bias in included studies. In: Higgins JPT, Green S (editors), Cochrane Handbook of Systematic Reviews of Intervention. Version 5.0.0 (updated February 2008). The Cochrane Collaboration, 2008. Available from www.cochrane-handbook.org.

\section{Kohn 2014}

Kohn DB. Clinical Research Study of Autologous Bone Marrow Transplantation for Sickle Cell Disease (SCD) Using Bone Marrow CD34+ Cells Modified With the Lenti/ßAS3-FB Lentiviral Vector. https://clinicaltrials.gov/show/NCT02247843.

\section{Lezcano 2006}

Lezcano NE, Odo N, Kutlar A, Brambilla D, Adams RJ . Regular transfusion lowers plasma free hemoglobin in children with sickle-cell disease at risk for stroke. Stroke 2006; Vol. 37, issue 6:1424-6.

\section{Manci 2003}

Manci EA, Culberson DE, Yang YM, Gardner TM, Powell R, Haynes J Jr, et al. Causes of death in sickle cell disease: an autopsy study. British Journal of Haematology 2003;123(2):359-65.

\section{Mankad 2001}

Mankad VN. Exciting new approaches for pathophysiologic mechanisms of sickle cell disease. Pediatric Pathology and Molecular Medicine 2001;20(1):1-13.

\section{May 2000}

May C, Rivella S, Callegari J. Therapeutic haemoglobin synthesis in beta-thalassaemic mice expressing lentivirus-encoded human betaglobin. Nature 2000;406(6791):82-6.

\section{Nathan 2001}

Nathan S. Gene Therapy for Sickle-Cell Disease?. Science News 2001; Vol. 160, issue 24:372.

\section{Ohene-Frempong 1994}

Ohene-Frempong K, Nkrumah FK. Sickle cell disease in Africa. Sickle cell disease: basic principles and clinical practice. New York: Raven Press Ltd, 1994.

\section{Persons 2003}

Persons DA, Nienhuis AW. Gene therapy for the hemoglobin disorders. Current Hematology Reports 2003;2(4):348-55.

\section{Platt 1991}

Platt OS, Thorington BD, Brambilla DJ, Milner PF, Rosse WF, Vichinsky E, et al. Pain in sickle cell disease. Rates and risk factors. New England Journal of Medicine 1991;325(24):11-6.

\section{Platt 1994}

Platt OS, Brambilla DJ, Rosse WF, Milner PF, Castro O, Steinberg MH, et al. Mortality in sickle cell disease: life expectancy and risk factors for early death. New England Journal of Medicine 1994;330(23):1639-43.

\section{Postnote 2005}

Postnote. Gene Therapy. UK Parliamentary Office of Science and Technology (www.parliament.uk/post) 2005 (accessed 07 July 2008), issue Number 240 .

\section{Powars 1983}

Powars D, Overturf G, Turner E. Is there an increased risk of Haemophilus influenzae septicemia in sickle cell anaemia? Pediatrics 1983;71(6):927-31.

\section{Powars 2002}

Powars DR, Hiti A, Ramicone E, Johnson C, Chan L. Outcome in hemoglobin SC disease: a four-decade observational study of clinical, hematologic and genetic factors. American Journal of Hematology 2002;70(3):206-15.

\section{Ribeil 2017}

Ribeil JA, Hacein-Bey-Abina S, Payen E, Magnani A, Semeraro M, Magrin E, et al. Gene therapy in a patient with sickle cell disease. New England Journal of Medicine 2017;376(9):848-55.

\section{Serjeant 1992}

Serjeant GR. Sickle cell disease. 2nd Edition. Oxford: Oxford University Press, 1992. 


\section{Serjeant 1993}

Serjeant GR, Serjeant BE. Management of sickle cell disease; lessons from the Jamaican Cohort Study. Blood Reviews 1993; 7(3):137-45.

\section{Steinberg 2003}

Steinberg MH, Barton F, Casto O, Pegelow CH, Ballas SK, Kutler A, et al. Effect of hydroxyurea on mortality and morbidity in adult sickle cell anemia: risks and benefits up to 9 years of treatment. JAMA 2003;289(13):1645-51.

\section{WHO 2006}

World Health Organization. Sickle-cell anaemia. Report A59/9. Provisional agenda item 11.4. 59th World Health Assembly. www.who.int/gb/ebwha/pdf_files/WHA59/A59_9-en.pdf 2006 (accessed 06 June 2008).

\section{APPEN DICES}

\section{Appendix 1. Search strategies - trial registries}

\section{References to other published versions of this review}

\section{Olowoyeye 2010}

Olowoyeye A, Okwundu $\mathrm{Cl}$. Gene therapy for sickle cell disease. Cochrane Database of Systematic Reviews 2010, Issue 8. [DOI: 10.1002/14651858.CD007652.pub2]

\section{Olowoyeye 2012}

Olowoyeye A, Okwundu $\mathrm{Cl}$. Gene therapy for sickle cell disease. Cochrane Database of Systematic Reviews 2012, Issue 11. [DOI: 10.1002/14651858.CD007652.pub3]

\section{Olowoyeye 2014}

Olowoyeye A, Okwundu Cl. Gene therapy for sickle cell disease. Cochrane Database of Systematic Reviews 2014, Issue 10. [DOI: 10.1002/14651858.CD007652.pub4]

\begin{tabular}{ll}
\hline Registry & Search terms \\
\hline WHO ICTRP & Advanced search \\
& Condition: sickle cell \\
& Intervention: gene therapy \\
& Phase: all \\
\hline ClinicalTrials.gov & Condition: sickle cell \\
& Other terms: gene therapy \\
Study type: interventional \\
Study results: all studies
\end{tabular}

WHAT'S NEW

\begin{tabular}{lll}
\hline Date & Event & Description \\
\hline 18 October 2018 & $\begin{array}{l}\text { New citation required but conclusions } \\
\text { have not changed }\end{array}$ & $\begin{array}{l}\text { The background section has been update. A case report that was } \\
\text { recently published on the use of gene therapy for sickle cell dis- } \\
\text { ease has been referenced, as has an ongoing trial (which will not } \\
\text { be eligible for this review). }\end{array}$ \\
\hline 18 October 2018 New search has been performed & $\begin{array}{l}\text { A search of the Cochrane Cystic Fibrosis and Genetic Disorders } \\
\text { Group's Haemoglobinopathies Trials Register did not identify } \\
\text { any potentially-relevant trials. Two studies were identified by the } \\
\text { search of trial registries, neither of which required further inves- } \\
\text { tigation (Kohn 2014; Ribeil 2017). }\end{array}$ \\
\hline
\end{tabular}




\section{HISTORY}

Protocol first published: Issue 1, 2009

Review first published: Issue 8, 2010

\begin{tabular}{|c|c|c|}
\hline Date & Event & Description \\
\hline 25 October 2016 & $\begin{array}{l}\text { New citation required but conclusions } \\
\text { have not changed }\end{array}$ & $\begin{array}{l}\text { Minor changes have been made throughout the review. The } \\
\text { 'Plain language summary' has been re-formatted. }\end{array}$ \\
\hline 25 October 2016 & New search has been performed & $\begin{array}{l}\text { The updated searches did not identify any potentially relevant } \\
\text { trials for inclusion in the review. }\end{array}$ \\
\hline 1 October 2014 & New search has been performed & $\begin{array}{l}\text { The updated searches did not identify any potentially relevant } \\
\text { trials for inclusion in the review. }\end{array}$ \\
\hline 1 October 2014 & $\begin{array}{l}\text { New citation required but conclusions } \\
\text { have not changed }\end{array}$ & Minor changes have been made throughout the review. \\
\hline 24 March 2014 & Amended & Contact details updated. \\
\hline 21 June 2012 & New search has been performed & $\begin{array}{l}\text { A search of the Group's Haemoglobinopathies Trials Register did } \\
\text { not identify any potentially eligible trials for inclusion in this re- } \\
\text { view. }\end{array}$ \\
\hline 21 June 2012 & $\begin{array}{l}\text { New citation required but conclusions } \\
\text { have not changed }\end{array}$ & $\begin{array}{l}\text { No new trials have been included in this update and no changes } \\
\text { have made to the conclusions of the review. }\end{array}$ \\
\hline 22 May 2012 & Amended & Contact details updated. \\
\hline 20 September 2010 & Amended & Contact details updated. \\
\hline
\end{tabular}

\section{CONTRIBUTIONS OF AUTHORS}

The authors contributed equally to the development of the review and update.

\section{DECLARATIONSOF INTEREST}

Both authors: none known.

\section{SOURCES OF SUPPORT}

\section{Internal sources}

- No sources of support supplied

\section{External sources}

- National Institute for Health Research, UK.

This systematic review was supported by the National Institute for Health Research, via Cochrane Infrastructure funding to the Cochrane Cystic Fibrosis and Genetic Disorders Group.

\section{DIFFERENCES BETWEEN PROTOCOL AND REVIEW}

In the published protocol one primary outcome was included. However, following on from comments by peer reviewers at draft review stage, it was thought necessary and appropriate to add an additional primary outcome on life expectancy. 
INDEX TERMS

\section{Medical Subject Headings (MeSH)}

*Genetic Therapy; Anemia, Sickle Cell [genetics] [therapy]

\section{MeSH check words}

Humans 